\title{
Sesquiterpenoids from the Rhizomes of Curcuma phaeocaulis and Their Inhibitory Effects on LPS-Induced TLR4 Activation
}

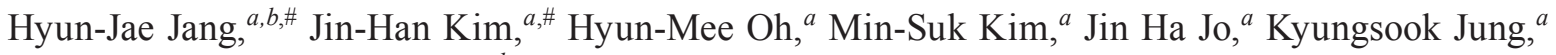 \\ Soyoung Lee, ${ }^{a}$ Young-Ho Kim ${ }^{b}{ }^{b}$ Woo Song Lee, ${ }^{a}$ Seung Woong Lee, ${ }^{*, a}$ and Mun-Chual Rho, ${ }^{* a}$ \\ ${ }^{a}$ Natural Product Research Center, Korea Research Institute of Bioscience and Biotechnology; Jeongeup-si, Jeonbuk \\ 56212, Republic of Korea: and ${ }^{b}$ College of Pharmacy, Chungnam National University; Daejeon 34134, Republic of \\ Korea. \\ Received January 26, 2016; accepted March 22, 2016
}

Two new guaiane-type $(2,6)$ and one new furanogermacrane-type (11) sesquiterpenoids have been isolated along with twelve known compounds from an EtOAc-soluble extract of Curcuma phaeocaulis rhizomes. The structures of the isolated compounds were elucidated using a combination of NMR, MS, and circular dichroism (CD) spectra. The inhibitory effects of each compound on lipopolysaccharide (LPS)-induced Tolllike receptor 4 (TLR4) activation in THP-1-Blue cells were assessed, and compound 4 showed more potent inhibitory activity against LPS-stimulated TLR4 activation.

Key words Curcuma phaeocaulis; Zingiberaceae; sesquiterpenoid; Toll-like receptor 4 (TLR4); lipopolysaccharide (LPS)

Curcuma phaeocaulis VALETON, a member of the family Zingiberaceae, is distributed across Korea, China, and Japan. ${ }^{1)}$ Its rhizomes have been broadly prescribed as a traditional remedy for reducing blood stasis and alleviating pain symptoms. ${ }^{2)}$ This plant has continually attracted attention from numerous scientists due to its various pharmacological activities, which include antiinflammatory, ${ }^{3)}$ antioxidative, ${ }^{4)}$ antitumor, ${ }^{5)}$ and hepatoprotective effects. ${ }^{6}$ (Prior phytochemical studies ${ }^{4,7)}$ have indicated that $C$. phaeocaulis contains diverse sesquiterpenoids and diarylheptanoids that contribute to the pharmacological effects of its rhizomes. ${ }^{7,8}$ )

Toll-like receptors (TLRs) have important functions in the innate immune system, which is responsible for eliminating infectious microorganisms, including bacteria, fungi, protozoa, and viruses. ${ }^{9,10)}$ However, unregulated TLR stimulation is a pathogenic mechanism of autoimmune ${ }^{11}$ and inflammatory diseases. ${ }^{12)}$ In particular, TLR4 is recognized by lipopolysaccharide (LPS), which is found in the cell walls of Gram-negative bacteria. The activation of TLR4 leads to the induction of nuclear factor kappa B (NF- $\kappa \mathrm{B})$ signaling cascades that initiate the production of pro-inflammatory molecules, including tumor necrosis factor alpha (TNF- $\alpha$ ), interleukin (IL)-6, IL-8, and IL-12. ${ }^{13)}$ This pathway is biologically important for regulating host homeostasis; however, the inability to regulate excessive TLR4 activation causes abnormal inflammatory responses.

\section{Results and Discussion}

In our ongoing studies of TLR4 inhibitors from traditional medicinal resources, we have determined that a 95\% EtOH extract of $C$. phaeocaulis rhizomes has a half maximal inhibitory concentration $\left(\mathrm{IC}_{50}\right)$ value of $8.8 \mu \mathrm{g} / \mathrm{mL}$. This extract was progressively fractionated with EtOAc, $n-\mathrm{BuOH}$, and $\mathrm{H}_{2} \mathrm{O}$, and the EtOAc-soluble fraction was subjected to various chromatographic experiments, which allowed us to isolate new guaiane-

\footnotetext{
\# These authors contributed equally to this work.

*To whom correspondence should be addressed. e-mail: lswdoc@kribb.re.kr; rho-m@kribb.re.kr
}

type $(\mathbf{2}, \mathbf{6})$, and furanogermacrane-type (11) sesquiterpenoids, as well as twelve known compounds: procurcumenol (1) ${ }^{14)}$ procurcumadiol (3), ${ }^{14)}$ zedoarondiol (4), ${ }^{15)}$ phaeocaulisine E (5), ${ }^{7)}$ wenyujinin L (7), ${ }^{16)}$ phacadinane B (8), ${ }^{17)}$ curcumenolactone A (9), ${ }^{6}$ curcumenolactone B (10), ${ }^{6}$ zedoarofuran (12) ${ }^{18)}$ curcolonol (13), ${ }^{8)} 4 \alpha$-hydroxy-8,12-epoxyeudesma-7,11diene-1,6-dione (14), ${ }^{19,20)}$ and neolitacumone A (15) ${ }^{21)}$ (Fig. 1). These known compounds were elucidated by comparing their spectroscopic profiles with previously published data.

Compound 2 was isolated as an amorphous white powder. This compound's molecular formula of $\mathrm{C}_{15} \mathrm{H}_{22} \mathrm{O}_{3}$ was deduced from high resolution-electrospray ionization (HR-ESI)-MS data (273.1461 $[\mathrm{M}+\mathrm{Na}]^{+}$, Calcd for 273.1467). Its IR spectrum included absorption bands for hydroxy $\left(3412 \mathrm{~cm}^{-1}\right)$ and conjugated carbonyl $\left(1650 \mathrm{~cm}^{-1}\right)$ groups. ${ }^{1} \mathrm{H}-\mathrm{NMR}$ spectral data (Table 1) for 2 revealed signals from four methyl groups $\left[\delta_{\mathrm{H}}\right.$ $1.78\left(\mathrm{~s}, \mathrm{H}_{3}-12\right), 1.75\left(\mathrm{t}, J=1.2 \mathrm{~Hz}, \mathrm{H}_{3}-13\right), 1.36\left(\mathrm{~s}, \mathrm{H}_{3}-14\right)$, and $\left.1.95\left(\mathrm{~d}, J=1.2 \mathrm{~Hz}, \mathrm{H}_{3}-15\right)\right]$, one methine proton $\left[\delta_{\mathrm{H}} 2.23(\mathrm{dd}\right.$, $J=11.4,4.8 \mathrm{~Hz}, \mathrm{H}-5)]$, and one olefinic proton $\left[\delta_{\mathrm{H}} 5.85(\mathrm{~d}\right.$, $J=1.2 \mathrm{~Hz}, \mathrm{H}-9)] \cdot{ }^{13} \mathrm{C}-\mathrm{NMR}$ and distortionless enhancement by polarization transfer (DEPT) data included 15 carbon signals produced by four methyl carbons $\left(\delta_{\mathrm{C}} 22.6,21.4,26.6,20.5\right)$, four olefinic carbons $\left(\delta_{\mathrm{C}} 135.6,130.2,152.6,137.8\right)$, three methylene carbons $\left(\delta_{\mathrm{C}} 35.8,39.1,22.7\right)$, and one carbonyl carbon $\left(\delta_{\mathrm{C}}\right.$ 198.5). One dimensional (1D)-NMR spectroscopic data for $\mathbf{2}$ were highly similar to NMR data for 1,4-dihydroxy7(11),9(10)-guaiandien-8-one, aerugidiol, ${ }^{22)}$ which was isolated from C. aeruginosa in 1991. A guaiane skeleton that includes two hydroxyl groups and one conjugated ketone group was demonstrated by the $\mathrm{H}_{3}-14 / \mathrm{C}-4, \mathrm{H}_{3}-15 / \mathrm{C}-1$ and $\mathrm{C}-9$, and $\mathrm{H}_{3}$ 12/C-8 heteronuclear multiple bond connectivity (HMBC) correlations (Fig. 2), suggesting that the planar structure of $\mathbf{2}$ was identical to that of aerugidiol. Similar nuclear Overhauser effect (NOE) correlations were observed between $\mathrm{H}_{2}-6 \alpha$ and $\mathrm{H}_{3}-14$; between $\mathrm{H}_{2}-3 \alpha$ and $\mathrm{H}_{3}-14$ for 2 and aerugidiol (Fig. 3); however, the optical rotation of 2 was estimated to be $[\alpha]_{\mathrm{D}}^{20}$ +267.4 (aerugidiol: lit. ${ }^{22)}[\alpha]_{\mathrm{D}}^{26}-17.0$ ), and its circular dichro- 


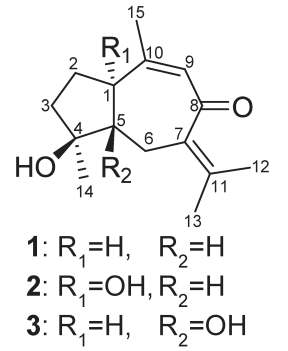<smiles>CC1=CC(=O)C[C@H]2[C@@H](C)CC[C@H]12</smiles>

7<smiles>[R]C1(C)CC(=O)C(=C(C)C)C[C@@H]2[C@H](C)[C@H](O)CC[C@H]21</smiles><smiles>CC1=CC(=O)C(=C(C)C)C2(O)CCC(C)C(=O)C12O</smiles><smiles>[R]C12C[C@]3(C)[C@@H](CCC(C)=O)[C@@H]3[C@]1([R])OC(=O)C2C</smiles><smiles>CC1=C2C(=O)c3c(C)coc3CC2(C)C(C)(C)CC[C@H]1O</smiles>

11<smiles>[R]C1CC[C@H](O)[C@]2([R5])C(=O)c3c(C)coc3C[C@]12C</smiles>

12: $\mathrm{R}_{1}=\alpha-\mathrm{OH}, \mathrm{R}_{2}=\beta-\mathrm{H}, \mathrm{R}_{3}=\alpha-\mathrm{CH}_{3}$ 13: $\mathrm{R}_{1}=\beta-\mathrm{OH}, \mathrm{R}_{2}=\alpha-\mathrm{H}, \mathrm{R}_{3}=\beta-\mathrm{CH}_{3}$
9: $\mathrm{R}=\beta-\mathrm{OH}$ 10: $\mathrm{R}=\alpha-\mathrm{OH}$<smiles>CCc1cc2c(c(C)cc1=O)CC[C@@]2(C)O</smiles>

6<smiles>C=C1CC[C@@H](O)[C@]2(C)C[C@]3(O)OC(=O)C(C)=C3CC12</smiles>

15

Fig. 1. Chemical Structures of the Isolated Compounds 1-15

Table 1. ${ }^{1} \mathrm{H}$ - and ${ }^{13} \mathrm{C}-\mathrm{NMR}$ Spectroscopic Data of Compounds 2, 6, and $\mathbf{1 1}^{a)}$

\begin{tabular}{|c|c|c|c|c|c|c|}
\hline \multirow{2}{*}{ Position } & \multicolumn{2}{|r|}{2} & \multicolumn{2}{|r|}{6} & \multicolumn{2}{|r|}{11} \\
\hline & $\delta_{\mathrm{C}}$ & $\delta_{\mathrm{H}}(J$ in $\mathrm{Hz})$ & $\delta_{\mathrm{C}}$ & $\delta_{\mathrm{H}}(J$ in $\mathrm{Hz})$ & $\delta_{\mathrm{C}}$ & $\delta_{\mathrm{H}}(J$ in $\mathrm{Hz})$ \\
\hline 1 & 83.2 & - & 147.5 & - & 77.0 & $4.20, \mathrm{dd}(9.0,3.6)$ \\
\hline \multirow[t]{2}{*}{2} & 35.8 & $1.95, \mathrm{~m}$ & 32.7 & 2.91, ddd $(17.4,9.0,3.0)$ & 34.6 & $2.19, \mathrm{~m}$ \\
\hline & & & & $2.79, \mathrm{dt}(17.4,7.8)$ & - & $2.08, \mathrm{~m}$ \\
\hline \multirow[t]{2}{*}{3} & 39.1 & $2.00, \mathrm{~m}$ & 40.1 & 2.19, ddd $(12.6,7.8,3.0)$ & 33.9 & $2.43 \mathrm{ddd}(14.4,7.2,2.4)$ \\
\hline & & $1.80, \mathrm{~m}$ & & $2.05, \mathrm{~m}$ & - & $2.04, \mathrm{~m}$ \\
\hline 4 & 81.1 & - & 84.7 & - & 146.2 & - \\
\hline 5 & 55.8 & $2.23, \mathrm{dd}(11.4,4.8)$ & 152.3 & - & 128.8 & $6.40, \mathrm{~s}$ \\
\hline \multirow[t]{2}{*}{6} & 22.7 & 2.46, brd $(11.4)$ & 133.6 & $7.50, \mathrm{~s}$ & 194.6 & - \\
\hline & & $1.74, \mathrm{~m}$ & & & - & - \\
\hline 7 & 135.6 & - & 156.0 & - & 123.3 & - \\
\hline 8 & 198.5 & - & 187.4 & - & 165.7 & - \\
\hline \multirow[t]{2}{*}{9} & 130.2 & $5.85, \mathrm{~d}(1.2)$ & 140.1 & $7.06, \mathrm{~s}$ & 33.3 & $3.80, \mathrm{~d}(17.4)$ \\
\hline & & & & & - & $3.50, \mathrm{~d}(17.4)$ \\
\hline 10 & 152.6 & - & 149.1 & - & 151.1 & - \\
\hline 11 & 137.8 & - & 29.6 & $2.67, \mathrm{q}(7.2)$ & 123.1 & - \\
\hline 12 & 21.4 & $1.78, \mathrm{~s}$ & 13.9 & $1.19, \mathrm{t}(7.2)$ & 140.4 & $7.24, \mathrm{~s}$ \\
\hline 13 & 22.6 & $1.75, \mathrm{t}(1.2)$ & 27.6 & $1.42, \mathrm{~s}$ & 10.2 & $2.18, \mathrm{~d}(0.6)$ \\
\hline \multirow[t]{2}{*}{14} & 26.6 & $1.36, \mathrm{~s}$ & 25.1 & $2.32, \mathrm{~s}$ & 112.8 & $5.08, \mathrm{~s}$ \\
\hline & - & - & - & - & - & $4.48, \mathrm{~s}$ \\
\hline 15 & 20.5 & $1.95, \mathrm{~d}(1.2)$ & - & - & 20.0 & $1.57, \mathrm{~s}$ \\
\hline
\end{tabular}

a) ${ }^{1} \mathrm{H}$ - and ${ }^{13} \mathrm{C}$-NMR spectroscopic data were recorded at 600 and $150 \mathrm{MHz}$, respectively. The spectrum of compound 2 was obtained in $\mathrm{CDCl}_{3}$, and the spectrum of compounds 6 and 11 were obtained in $\mathrm{CD}_{3} \mathrm{OD}$.

ism (CD) cotton effects, which were observed at $239 \mathrm{~nm}(\Delta \varepsilon$ -33.2), $279 \mathrm{~nm}(\Delta \varepsilon+15.7)$, and $346 \mathrm{~nm}(\Delta \varepsilon+8.5)$, were opposed to those of aerugidiol, ${ }^{22)}$ indicating that $\mathbf{2}$ is a stereoisomer of aerugidiol. Likewise, completely different CD spectra pattern have been observed for $\mathbf{1}$ and epiprocurcumenol, which is similar to $\mathbf{2}$ and aerugidiol due to a difference of these compounds' configurations at C-1. ${ }^{14)}$ The CD spectrum of 2 suggested that it had the same absolute configuration as those of 1. Therefore, 2 and aerugidiol might be epimers at $\mathrm{C}-1$, and 2 was determined to be $(1 S, 4 S, 5 R)-1,4$-dihydroxy- 


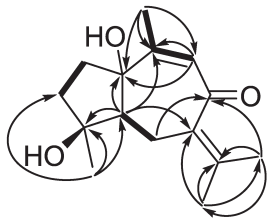

2

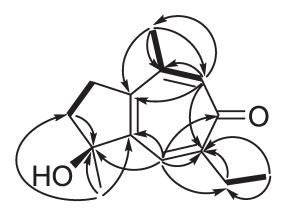

6

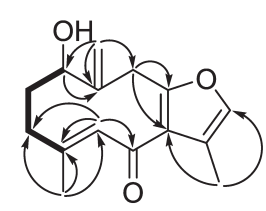

11

\section{$\longrightarrow{ }^{1} \mathrm{H}-{ }^{1} \mathrm{H}$ COSY $\longrightarrow \mathrm{HMBC}$}

Fig. 2. Key ${ }^{1} \mathrm{H}-{ }^{1} \mathrm{H}$ COSY and HMBC Correlations of Compounds 2, 6, and $\mathbf{1 1}$

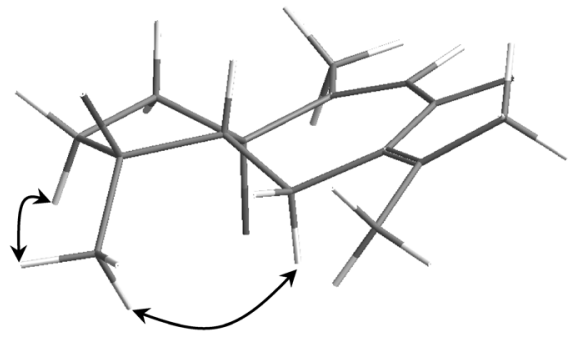

2

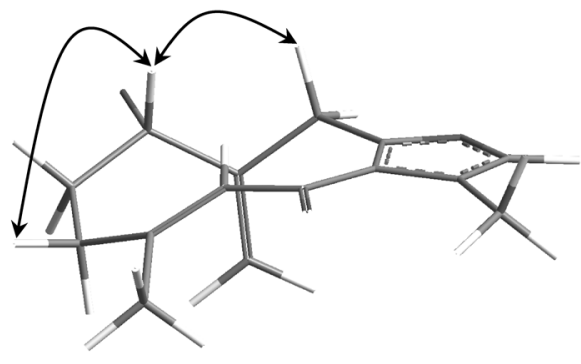

11

\section{Key NOESY correlations}

Fig. 3. Key NOESY Correlations of Compounds $\mathbf{2}$ and $\mathbf{1 1}$

7(11),9(10)-guaidien-8-one; this compound was named 1-epiaerugidiol.

Compound 6 was obtained as a yellow syrup, and its molecular formula of $\mathrm{C}_{14} \mathrm{H}_{18} \mathrm{O}_{2}$ was determined based on a pseudo-molecular ion peak in the HR-ESI-MS spectrum at $\mathrm{m} / \mathrm{z}$ of $219.1380\left([\mathrm{M}+\mathrm{H}]^{+}\right.$, Calcd for 219.1385). Its IR spectrum indicated the presence of a hydroxyl group $\left(3403 \mathrm{~cm}^{-1}\right)$ and a conjugated carbonyl group $\left(1667 \mathrm{~cm}^{-1}\right)$. Its ${ }^{1} \mathrm{H}-\mathrm{NMR}$ spectrum (Table 1) included three methyl signals $\left[\delta_{\mathrm{H}} 1.19(\mathrm{t}, J=7.2 \mathrm{~Hz}\right.$, $\left.\mathrm{H}_{3}-12\right), 1.42$ (s, $\left.\left.\mathrm{H}_{3}-13\right), 2.32\left(\mathrm{~s}, \mathrm{H}_{3}-14\right)\right]$ and two olefinic proton signals $\left[\delta_{\mathrm{H}} 7.50(\mathrm{~s}, \mathrm{H}-6), 7.06(\mathrm{~s}, \mathrm{H}-9)\right] .{ }^{13} \mathrm{C}-\mathrm{NMR}$ spectroscopic data, including DEPT spectra, contained 14 carbon signals, which included six olefinic carbons $\left(\delta_{\mathrm{C}} 147.5,152.3\right.$, $133.6,156.0,140.1,149.1)$ and one conjugated carbonyl group $\left(\delta_{\mathrm{C}}\right.$ 187.4). With respect to NMR data, 6 was similar to a previously isolated guaiane-type sesquiterpenoid, phaeocaulisin $\mathrm{D},{ }^{7)}$ but differed due to the absence of one methyl group and one hydroxy group. This conclusion was further supported by the HMBC correlations between H-6 and C-5, C-8, and C-11; between the other olefinic proton $\mathrm{H}-9$ and $\mathrm{C}-1, \mathrm{C}-7$, and $\mathrm{C}-14$; and between the ethyl group $\left(\mathrm{H}_{2}-11, \mathrm{H}_{3}-12\right)$ and $\mathrm{C}-7$. Finally, the oxygenated quaternary carbon $\mathrm{C}-4$ was correlated with the methylene proton $\mathrm{H}_{2}-3$, the olefinic proton $\mathrm{H}-6$, and the methyl proton $\mathrm{H}_{3}-13$ (Fig. 2). Accordingly, 6 was an analog of phaeocaulisin $\mathrm{D}$; thus, this compound possessed a guaiane sesquiterpenoid moiety and a chiral center at C-4. Using the empirical bulkiness rule developed by Frelek and Szczepek, ${ }^{23)}$ the absolute configuration of $\mathbf{6}$ at C-4 was determined to be $S$ based on the positive Cotton effect at approximately $340 \mathrm{~nm}$ $(\Delta \varepsilon+0.13)$ in the $\mathrm{Rh}_{2}\left(\mathrm{OCOCF}_{3}\right)_{4}$-induced $\mathrm{CD}$ spectrum. ${ }^{7,23)}$ This result was in good agreement with $\mathrm{CD}$ data for $\mathrm{Rh}$-complexes of the analogous compound phaeocaulisin D. ${ }^{7)}$ Thus, 6 was determined to be (4S)-7-ethyl-4-hydroxy-1(5),6(7),9(10)- guaiatrien-8-one; this compound was named phaeocaulisin R.

Compound $\mathbf{1 1}$ was obtained as a yellow syrup, and its molecular formula was determined to be $\mathrm{C}_{15} \mathrm{H}_{18} \mathrm{O}_{3}$ by HRESI-MS data (247.1326 [M+H] ${ }^{+}$, Calcd for 247.1334). The IR spectrum displayed absorption bands for hydroxyl $\left(3423 \mathrm{~cm}^{-1}\right)$, conjugated carbonyl group $\left(1643 \mathrm{~cm}^{-1}\right)$, and double bonds (1535). Its ${ }^{1} \mathrm{H}-\mathrm{NMR}$ spectrum (Table 1) showed signals for two methyl protons $\left[\delta_{\mathrm{H}} 2.18\left(\mathrm{~d}, J=0.6 \mathrm{~Hz}, \mathrm{H}_{3}-13\right)\right.$ and $\delta_{\mathrm{H}} 1.57(\mathrm{~s}$, $\left.\left.\mathrm{H}_{3}-15\right)\right]$, one oxygenated methine proton $\left[\delta_{\mathrm{H}} 4.20\right.$ (dd, $J=9.0$, $3.6 \mathrm{~Hz}, \mathrm{H}-1)]$, a pair of olefinic protons on exo-cyclic double bonds $\left[\delta_{\mathrm{H}} 5.08\left(\mathrm{~s}, \mathrm{H}_{2}-14 \mathrm{a}\right), 4.48\left(\mathrm{~s}, \mathrm{H}_{2}-14 \mathrm{~b}\right)\right]$, and another olefinic proton $\left[\delta_{\mathrm{H}} 7.24(\mathrm{~s}, \mathrm{H}-12)\right]$. The ${ }^{13} \mathrm{C}-\mathrm{NMR}$ and DEPT spectra of 11 indicated the presence of 15 carbons, including eight olefinic carbons $\left(\delta_{\mathrm{C}} 146.2,128.8,123.3,165.7,151.1,123.1\right.$, $140.4,112.8)$, three methylene carbons $\left(\delta_{\mathrm{C}} 34.6,33.9,33.3\right)$, two methyl carbons $\left(\delta_{\mathrm{C}} 20.0,10.2\right)$, one oxygenated secondary carbon $\left(\delta_{\mathrm{C}} 77.0\right)$, and one carbonyl carbon $\left(\delta_{\mathrm{C}} 194.6\right)$. The connectivity of $\mathrm{C}-1$ to $\mathrm{C}-3$ was established by ${ }^{1} \mathrm{H}-{ }^{1} \mathrm{H}$ correlation spectroscopy (COSY) correlations between $\mathrm{H}_{2}-2$ and $\mathrm{H}-1$, $\mathrm{H}_{2}-3$, and the HMBC correlations from $\mathrm{H}-1$ to $\mathrm{C}-10$, from $\mathrm{H}-5$ to $\mathrm{C}-3, \mathrm{C}-4$, and $\mathrm{C}-6$, from $\mathrm{H}_{2}-9$ to $\mathrm{C}-8$ and $\mathrm{C}-7$, from $\mathrm{H}_{3}-13$ to $\mathrm{C}-7$ and $\mathrm{C}-12$, from $\mathrm{H}_{2}-14$ to $\mathrm{C}-1, \mathrm{C}-9$, and $\mathrm{C}-10$, and from $\mathrm{H}_{3}-15$ to $\mathrm{C}-3, \mathrm{C}-4, \mathrm{C}-5$ were supportive of the structure shown in Fig. 1. The partial moieties of $\mathbf{1 1}$ adjacent to $\mathrm{C}-1$ were similar to those of 1-epi-dihydrochrysanolide, ${ }^{24)}$ which comprised those of the secondary hydroxyl group and the exo-cyclic double bond at C-1 and C-14, and lactone moieties instead of conjugated furan group of 11. NOE correlations between $\mathrm{H}-1$ and $\mathrm{H}_{2}-3 \beta\left(\delta_{\mathrm{H}} 2.04, \mathrm{~m}\right)$ and $\mathrm{H}_{2}-9 \beta\left[\delta_{\mathrm{H}} 3.50, \mathrm{~d}(17.4)\right]$ were observed on the nuclear Overhauser effect spectroscopy (NOESY) spectrum of 11, suggesting that $\mathrm{H}-1, \mathrm{H}_{2}-3 \beta$, and $\mathrm{H}_{2}-9 \beta$ were in the same orientation (Fig. 3). The modified Mosher's ester method (Fig. 4) were used to determine the absolute configurations 


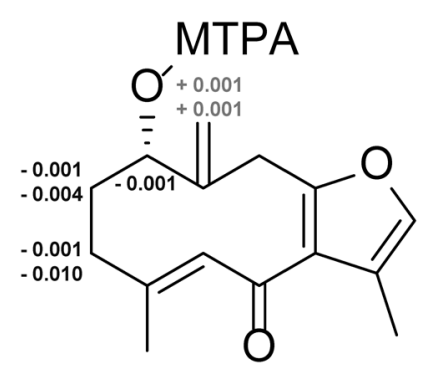

Fig. 4. $\Delta \delta$ Values $\left(\delta_{S}-\delta_{R}\right)$ in ppm of the MTPA Esters [(R)-MPTA (11a), $(S)$-MTPA (11b)]

of $11,{ }^{25)}$ and it was thus identified as $(1 S)$-1-hydroxy-8,12epoxygermacra-4(5),7(8),10(14),11(12)-tetraen-6-one; this compound was named $(1 S)$-1-hydroxy-isofuranodienone.

The THP-1-Blue cell line, which stably expresses NF- $\kappa$ Band AP-1-inducible reporter genes such as secreted embryonic alkaline phosphatase (SEAP) upon LPS stimulation, was used to evaluate the inhibitory effects of our isolated compounds 1-15 on TLR4 activation. ${ }^{26)}$ THP-1-Blue cells were stimulated with LPS $(50 \mathrm{ng} / \mathrm{mL})$ for $18 \mathrm{~h}$ in the presence of each compounds 1-15. LPS-induced TLR4 activation was inhibited by 4, 8, and 9 [with an $\mathrm{IC}_{50}$ value of $22.5 \pm 1.0 \mu \mathrm{M}(4), 54.8 \pm 1.2 \mu \mathrm{M}$ (8), $91.0 \pm 6.3 \mu \mathrm{M}(9)]$ relative to the positive control luteolin $\left(\mathrm{IC}_{50}\right.$ value: $\left.2.6 \pm 0.8 \mu \mathrm{M}\right){ }^{27)}$ whereas the remaining compounds showed little to no inhibition. Interestingly, 5, a 10-epimer of 4 that exhibits a $\beta$-orientation at $\mathrm{OH}-10$, produced no inhibitory effects $\left(\mathrm{IC}_{50}>100 \mu \mathrm{M}\right)$, suggesting that in guaiane-type sesquiterpenoids, the configuration at $\mathrm{OH}-10$ may affect the inhibition of TLR4 activity.

In this study, three new and twelve known sesquiterpenoids were isolated from the EtOAc-soluble fraction of $C$. phaeocaulis, and the inhibitory effects of each isolated compound 1-15 on LPS-induced TLR4 activation were assessed. Recent studies have indicated that zedoarondiol (4) inhibits proinflammatory cytokines, such as TNF- $\alpha$, IL- $1 \beta$, and IL- 6 , in LPS-stimulated murine macrophages by suppressing NF- $\kappa \mathrm{B}$ transcriptional activity. ${ }^{28)}$ Taken together, these findings suggest that sesquiterpenoids from $C$. phaeocaulis may be promising as inhibitors for TLR4-mediated inflammatory disease. Additional research is needed to evaluate relatively effective new candidate compounds that could target LPS-stimulated TLR4 activity.

\section{Experimental}

General Procedures Optical rotation was measured on a JASCO P-2000 (Jasco Co., Tokyo, Japan) polarimeter. UV spectra were determined on a Spectramax $\mathrm{M}_{2}{ }^{\mathrm{e}}$ (Molecular Devices, Sunnyvale, CA, U.S.A.) spectrophotometer. CD spectra were recorded on a JASCO J-710 (Jasco Co.) spectropolarimeter. IR spectra data were measured on a Spectrum GX (Perkin-Elmer, Wellesley, MA, U.S.A.) Fourier transform (FT)-IR spectrometer. ${ }^{1} \mathrm{H}-,{ }^{13} \mathrm{C}$-, and $2 \mathrm{D}-\mathrm{NMR}$ spectroscopic data were recorded on a JEOL JNM-ECA600 or JEOL JNMEX400 (JEOL, Tokyo, Japan) instrument using tetramethyl silane (TMS) as a reference. HR-ESI mass spectrum data were obtained on Bruker maXis 4G (Bruker, Bremen, Germany) spectrometer. Column chromatography was performed with silica gel (Kieselgel 60, 230-400 mesh, Merck, Darmstadt, Germany), and silica gel $60 \mathrm{~F}_{254}$ and RP-18 $\mathrm{F}_{254} \mathrm{~s}$ (Merck) were used for TLC profiling. Medium pressure liquid chromatog- raphy (MPLC) was performed on a Combiflash RF (Teledyne Isco, Lincoln, NE, U.S.A.), and preparative HPLC was carried out on a Shimadzu LC-6AD (Shimadzu Co., Kyoto, Japan) instrument equipped with a SPD-20 A detector using a Phenomenex Luna $\mathrm{C}_{18}(250 \mathrm{~mm} \times 21.2 \mathrm{~mm}, 5 \mu \mathrm{m}$, Phenomenex Luna, Torrance, CA, U.S.A.). $(R)$ - and $(S)-\alpha$-Methoxy- $\alpha$ (trifluoromethyl)-phenylacetyl (MTPAs) were purchased from TCI, Co., Ltd. (Tokyo, Japan).

Plant Material C. phaeocaulis rhizomes were purchased from an herbal store in Jeongeup, Korea, in April 2014. One of the authors (M.-C. Rho) performed botanical identification, and a voucher specimen (KRIBB-KR2014-700) has been deposited at the laboratory of Eco-friendly Material Research Center, Jeonbuk Branch of the Korea Research Institute of Bioscience and Biotechnology.

Extraction and Isolation Dried and pulverized C. phaeocaulis rhizomes $(4 \mathrm{~kg})$ were extracted at room temperature with $95 \% \mathrm{EtOH}(40 \mathrm{~L} \times 3)$, and the filtrate was evaporated in vacuo to obtain an EtOH extract $(283 \mathrm{~g})$. This extract was suspended in $\mathrm{H}_{2} \mathrm{O}$ and progressively partitioned with EtOAc $(151 \mathrm{~g})$ and $\mathrm{BuOH}(46 \mathrm{~g})$. The EtOAc-soluble extract was chromatographed on a silica gel column using a stepwise gradient of a hexane-EtOAc $(1: 0-0: 1)$ solvent system to generate 38 sub-fractions (CPE1-CPE38). CPE14 (5.2 g) was separated by $\mathrm{C}_{18}$ MPLC to produce 17 sub-fractions (CPE14A-CPE14Q) using a gradient solvent system composed of $\mathrm{H}_{2} \mathrm{O}$ and $\mathrm{MeOH}$ (30-100\%), and SPE14D (815 mg) was re-chromatographed by $\mathrm{C}_{18}$ MPLC to generate 4 fractions (CPE14D1-CPE14D4). CPE14D1 (39.3 mg) was further purified by preparative HPLC $(40 \% \mathrm{MeCN}, 6 \mathrm{~mL} / \mathrm{min})$ to produce $9(3.2 \mathrm{mg})$ and $\mathbf{1 0}(1.6 \mathrm{mg})$. Compounds $11(15.8 \mathrm{mg})$ and $\mathbf{1 2}(83.2 \mathrm{mg})$ were separated from CPE14D3 (379 mg) by using preparative HPLC $(25 \%$ $\mathrm{MeCN}, 6 \mathrm{~mL} / \mathrm{min})$. Compounds $\mathbf{1}(263.1 \mathrm{mg})$ and $14(4.4 \mathrm{mg})$ were isolated from CPE14I $(540 \mathrm{mg})$ by preparative HPLC (50\% MeCN, $6 \mathrm{~mL} / \mathrm{min})$. CPE19 (2.2 g) was chromatographed by $\mathrm{C}_{18}$ MPLC and eluted with $\mathrm{H}_{2} \mathrm{O}$ and $\mathrm{MeOH}(20-100 \%)$. Among the resulting sub-fractions (CPE19A-CPE19P), CPE19D $(101.2 \mathrm{mg})$ was separated by preparative HPLC $(25 \% \mathrm{MeCN}$, $6 \mathrm{~mL} / \mathrm{min})$ to produce $2(33.4 \mathrm{mg}), 4(8.3 \mathrm{mg}), 7(2.8 \mathrm{mg})$, and $8(8.7 \mathrm{mg})$. Furthermore, CPE19H $(155.8 \mathrm{mg})$ was separated by preparative HPLC $(25 \% \mathrm{MeCN}, 6 \mathrm{~mL} / \mathrm{min})$ to yield $3(2.9 \mathrm{mg})$, $5(21.4 \mathrm{mg}), \mathbf{6}(1.6 \mathrm{mg})$, and $\mathbf{1 5}(17.1 \mathrm{mg})$. In addition, $\mathbf{1 3}$ $(143.9 \mathrm{mg})$ was isolated from CPE19I $(240 \mathrm{mg})$ by preparative HPLC (25\% MeCN, $6 \mathrm{~mL} / \mathrm{min})$.

1-Epiaerugidiol (2)

Amorphous white powder, $[\alpha]_{\mathrm{D}}^{20}+267.4\left(c=0.1, \mathrm{CHCl}_{3}\right)$; $\mathrm{UV}\left(\mathrm{CHCl}_{3}\right) \lambda_{\max }(\log \varepsilon) 239 \mathrm{~nm}(1.91)$ and $317 \mathrm{~nm}(1.46)$; CD $\left(\mathrm{CHCl}_{3}\right) \lambda_{\max }(\Delta \varepsilon) 239 \mathrm{~nm}(-33.2), 279 \mathrm{~nm}(+15.7)$, and $346 \mathrm{~nm}$ $(+8.5)$; IR (KBr) $v_{\max } 3412,2968,2920,2853,1650,1442$, 1376, 1306, 1225, 1043, 922, and $759 \mathrm{~cm}^{-1} ;{ }^{1} \mathrm{H}-$ and ${ }^{13} \mathrm{C}-\mathrm{NMR}$ data, see Table 1; HR-ESI-MS m/z $273.1461 \quad\left(\mathrm{C}_{15} \mathrm{H}_{22} \mathrm{O}_{3} \mathrm{Na}\right.$, Calcd for 273.1467).

Phaeocaulisin R (6)

Yellow syrup, $[\alpha]_{\mathrm{D}}^{20}+45.0\left(c=0.1, \mathrm{CHCl}_{3}\right) ; \mathrm{UV}\left(\mathrm{CHCl}_{3}\right)$ $\lambda_{\text {max }}(\log \varepsilon) 239 \mathrm{~nm}(2.02)$ and $276 \mathrm{~nm}(1.84) ; \mathrm{Rh}_{2}\left(\mathrm{OCOCF}_{3}\right)_{4}{ }^{-}$ induced $\mathrm{CD}\left(\mathrm{CHCl}_{3}\right) \lambda_{\text {max }}(\Delta \varepsilon) 340 \mathrm{~nm}(+0.1)$; IR $(\mathrm{KBr}) v_{\max }$ 3403, 2967, 2928, 2856, 1667, 1507, 1461, 1193, 1163, 859, 786, and $738 \mathrm{~cm}^{-1}$; ${ }^{1} \mathrm{H}-$ and ${ }^{13} \mathrm{C}-\mathrm{NMR}$ data, see Table 1; HR-ESIMS $m / z 273.1380\left(\mathrm{C}_{14} \mathrm{H}_{19} \mathrm{O}_{2}\right.$, Calcd for 219.1385).

1-Hydroxy-isofuranodienone (11)

Yellow syrup, $[\alpha]_{\mathrm{D}}^{20}+6.0\left(c=0.1, \mathrm{CH}_{3} \mathrm{OH}\right) ; \mathrm{UV}\left(\mathrm{CH}_{3} \mathrm{OH}\right)$ 
$\lambda_{\max }(\log \varepsilon) 203 \mathrm{~nm}(2.14)$ and $256 \mathrm{~nm}(1.70) ; \mathrm{IR}(\mathrm{KBr}) v_{\max }$ 3423, 2927, 2886, 1643, 1535, 1409, 1384, 1262, 1027, and $893 \mathrm{~cm}^{-1}$; ${ }^{1} \mathrm{H}$ - and ${ }^{13} \mathrm{C}-\mathrm{NMR}$ data, see Table 1; HR-ESI-MS $m / z 247.1326\left(\mathrm{C}_{15} \mathrm{H}_{19} \mathrm{O}_{3}\right.$, Calcd for 247.1334).

Preparation of $(R)$ - and $(S)$-MTPA Ester of 11 (11a, b) Compounds $\mathbf{1 1}(4 \mathrm{mg})$ and 4-dimethylaminopyridine (4-DMAP) were dissolved in anhydrous pyridine $(1 \mathrm{~mL})$, and transfer into each vials for both $R$ - and $S$-MTPA acylation reactions. After being dried in a $\mathrm{N}_{2}$ gas stream for $3 \mathrm{~h}$, bis- $(R)$ and $(S)$-MTPA-Cl $(25 \mathrm{mg})$ were added, and each mixture was kept at $40^{\circ} \mathrm{C}$ in a water bath for $5 \mathrm{~h}$. The MTPA derivatives were purified by semi-preparative HPLC using a $\mathrm{C}_{18}$ column, eluting with a gradient solvent system composed of $\mathrm{H}_{2} \mathrm{O}$ and acetonitrile (35-100\%). (R)-MTPA ester (11a, $0.4 \mathrm{mg})$ : amorphous powder; ${ }^{1} \mathrm{H}-\mathrm{NMR}\left(600 \mathrm{MHz}\right.$, pyridine- $\left.d_{5}\right), \delta: 7.32(1 \mathrm{H}$, s, H-12), $6.50(1 \mathrm{H}, \mathrm{s}, \mathrm{H}-5), 5.14\left(1 \mathrm{H}, \mathrm{s}, \mathrm{H}_{2}-14 \mathrm{a}\right), 4.82(1 \mathrm{H}, \mathrm{s}$, $\left.\mathrm{H}_{2}-14 \mathrm{~b}\right), 4.75$ (1H, s, H-1), $4.03(1 \mathrm{H}, \mathrm{d}, J=17.4 \mathrm{~Hz}), 3.76(1 \mathrm{H}, \mathrm{d}$, $J=17.4 \mathrm{~Hz}), 2.38\left(5 \mathrm{H}, \mathrm{m}, \mathrm{H}_{2}-3 \mathrm{a}\right), 2.35\left(5 \mathrm{H}, \mathrm{s}, \mathrm{H}_{3}-13\right), 2.29(1 \mathrm{H}$, m, $\left.\mathrm{H}_{2}-2 \mathrm{a}\right), 2.29$ (1H, m, $\left.\mathrm{H}_{2}-2 \mathrm{~b}\right), 2.14\left(2 \mathrm{H}, \mathrm{m}, \mathrm{H}_{2}-3 \mathrm{~b}\right), 1.58(3 \mathrm{H}$, $\left.\mathrm{s}, \mathrm{H}_{3}-15\right)$. ( $S$ )-MTPA ester (11b, $\left.0.5 \mathrm{mg}\right)$ : amorphous powder; ${ }^{1} \mathrm{H}-\mathrm{NMR}\left(600 \mathrm{MHz}\right.$, pyridine- $\left.d_{5}\right), \delta: 7.32(1 \mathrm{H}, \mathrm{s}, \mathrm{H}-12), 6.50$ (1H, s, H-5), 5.14 (1H, s, H $-14 \mathrm{a}), 4.82\left(1 \mathrm{H}, \mathrm{s}, \mathrm{H}_{2}-14 \mathrm{~b}\right), 4.75$ $(1 \mathrm{H}, \mathrm{s}, \mathrm{H}-1), 4.03(1 \mathrm{H}, \mathrm{d}, J=17.4 \mathrm{~Hz}), 3.76(1 \mathrm{H}, \mathrm{d}, J=17.4 \mathrm{~Hz})$, 2.37 (5H, m, H $-3 \mathrm{a}), 2.35$ (5H, s, $\left.\mathrm{H}_{3}-13\right), 2.28$ (1H, m, $\left.\mathrm{H}_{2}-2 \mathrm{a}\right)$, $2.13\left(1 \mathrm{H}, \mathrm{m}, \mathrm{H}_{2}-2 \mathrm{~b}\right), 2.05\left(2 \mathrm{H}, \mathrm{m}, \mathrm{H}_{2}-3 \mathrm{~b}\right), 1.58\left(3 \mathrm{H}, \mathrm{s}, \mathrm{H}_{3}-15\right)$.

Measurement of Inhibitory Effect on TLR4 Activation THP-1-Blue cells were purchased from a commercial supplier (InvivoGen Corp., San Diego, CA, U.S.A.). TLR4 activity was evaluated according to the manufacturer's protocol, with the modifications described in our previous studies. ${ }^{27)}$

Acknowledgments This research was a part of the project titled 'Development of feed additive for fishery immune stimulation,' funded by the Ministry of Oceans and Fisheries and was supported by a Grant from the KRIBB Research Initiative Program, Republic of Korea (KGM2221622).

Conflict of Interest The authors declare no conflict of interest.

\section{References}

1) Yang F. Q., Li S. P., Chen Y., Lao S. C., Wang Y. T., Dong T. T., Tsim K. W., J. Pharm. Biomed. Anal., 39, 552-558 (2005).

2) Xia Q., Zhao K. J., Huang Z. G., Zhang P., Dong T. T., Li S. P., Tsim K. W., J. Agric. Food Chem., 53, 6019-6026 (2005).

3) Oh S., Han A. R., Park H. R., Jang E. J., Kim H. K., Jeong M. G.,
Song H., Park G. H., Seo E. K., Hwang E. S., Chem. Biodivers., 11, 1034-1041 (2014)

4) Hao Y. F., Lu C. L., Li D. J., Zhu L., Jiang J. G., Piao J. H., Food Funct., 5, 1369-1373 (2014).

5) Chen X., Pei L., Zhong Z., Guo J., Zhang Q., Wang Y., Phytomedicine, 18, 1238-1243 (2011).

6) Matsuda H., Morikawa T., Ninomiya K., Yoshikawa M., Bioorg. Med. Chem., 9, 909-916 (2001).

7) Liu Y., Ma J., Zhao Q., Liao C., Ding L., Chen L., Zhao F., Qiu F., J. Nat. Prod., 76, 1150-1156 (2013).

8) Syu W. J., Shen C. C., Don M. J., Ou J. C., Lee G. H., Sun C. M., J. Nat. Prod., 61, 1531-1534 (1998).

9) Medzhitov R., Nat. Rev. Immunol., 1, 135-145 (2001).

10) Pasare C., Medzhitov R., Nature (London), 438, 364-368 (2005).

11) Li M., Zhou Y., Feng G., Su S. B., Mol. Med., 9, 365-374 (2009).

12) Anwar M. A., Basith S., Choi S., Mol. Med., 45, e11 (2013).

13) Wang Y., Chen T., Han C., He D., Liu H., An H., Cai Z., Cao X., Blood, 110, 962-971 (2007).

14) Ohshiro M., Kuroyanagi M., Ueno A., Phytochemistry, 29, 2201 2205 (1990)

15) Kuroyanagi M., Ueno A., Ujiie K., Sato S., Chem. Pharm. Bull., 35, 53-59 (1987)

16) Yin G. P., Li L. C., Zhang Q. Z., An Y. W., Zhu J. J., Wang Z. M., Chou G. X., Wang Z. T., J. Nat. Prod., 77, 2161-2169 (2014).

17) Ma J., Wang Y., Liu Y., Gao S., Ding L., Zhao F., Chen L., Qiu F. Fitoterapia, 103, 90-96 (2015).

18) Matsuda H., Morikawa T., Toguchida I., Ninomiya K., Yoshikawa M., Chem. Pharm. Bull., 49, 1558-1566 (2001).

19) Wu B., He S., Wu X. D., Pan Y. J., Chem. Biodivers., 5, 1298-1303 (2008).

20) Yuan T., Zhang C. R., Yang S. P., Yin S., Wu W. B., Dong L., Yue J. M., J. Nat. Prod., 71, 2021-2025 (2008).

21) Chang F. R., Hsieh T. J., Huang T. L., Chen C. Y., Kuo R. Y., Chang Y. C., Chiu H. F., Wu Y. C., J. Nat. Prod., 65, 255-258 (2002).

22) Masuda T., Jitoe A., Nakatani N., Chem. Lett., 20, 1625-1628 (1991).

23) Frelek J., Szczepek W. J., Tetrahedron Asymmetry, 10, 1507-1520 (1999).

24) Lee K. D., Yang M. S., Ha T. J., Park K. M., Park K. H., Biosci. Biotechnol. Biochem., 66, 862-865 (2002).

25) Hoye T. R., Jeffrey C. S., Shao F., Nat. Protoc., 2, 2451-2458 (2007)

26) Hwang J. T., Oh H. M., Kim M. H., Jeong H. J., Lee C., Jang H. J., Lee S. W., Park C. S., Rho M. C., Molecules, 19, 10309-10319 (2014).

27) Lee J. K., Kim S. Y., Kim Y. S., Lee W. H., Hwang D. H., Lee J. Y., Biochem. Pharmacol., 77, 1391-1400 (2009).

28) Cho W., Nam J. W., Kang H. J., Windono T., Seo E. K., Lee K. T., Int. Immunopharmacol., 9, 1049-1057 (2009). 